\title{
UPAYA MENINGKATKAN KEMAMPUAN PEMECAHAN MASALAH MATEMATIKA SISWA MELALUI STRATEGI PROBLEM BASED LEARNING PADA KELAS VIII-C SMP MUHAMMADIYAH 29 SAWANGAN DEPOK
}

\author{
Erwin Sulaeman ${ }^{1)}$, dkk dan Arlin Astriyani ${ }^{2)}$ \\ Universitas Muhammadiyah Jakarta \\ 1) erwinsulaimanblue@gmail.com \\ 2)arlin_0717@yahoo.com
}

\begin{abstract}
Abstrak
Penelitian ini dimaksudkan untuk mengetahui peningkatan kemampuan pemecahan masalah matematika siswa melalui strategi problem based learning pada kelas VIII-C SMP Muhammadiyah 29 Sawangan Depok materi bangun ruang sisi datar pokok bahasan prisma dan limas. Subjek pada penelitian ini adalah siswa kelas VIII-C SMP Muhammadiyah 29 Sawangan-Depok dengan jumlah total 34 orang terdiri atas 24 orang siswa laki-laki dan 10 orang siswa perempuan. Instrumen yang digunakan dalam penelitian ini adalah instrumen tes bentuk uraian dan instrumen non tes lembar observasi. Metode penelitian yang digunakan dalam penelitian ini adalah Penelitian Tindakan Kelas (PTK) atau Classroom Action Research (CAR). Desain penelitian yang digunakan adalah desain dengan alur Model Lewin. Prosedur penelitian meliputi tiga siklus yang setiap siklusnya terdiri dari; rencana, tindakan, observasi, dan refleksi. Adapun kriteria keberhasilan tindakan yang diperoleh minimal $70 \%$ dari rata-rata pada setiap siklusnya. Analisis data pada penelitian ini menggunakan data kualitatif, yang mengikuti konsep yang diberikan Hiles dan Huberman yang terdiri dari; pengumpulan data, reduksi data dan penarikan kesimpulan. Hasil penelitian menunjukkan bahwa terdapat peningkatan kemampuan pemecahan masalah matematika siswa melalui strategi problem based learning pada materi bangun ruang sisi datar pokok bahasan prisma dan limas.
\end{abstract}

Kata kunci: Problem Based Learning, Pemecahan Masalah Matematika

\section{PENDAHULUAN}

Aktivitas pembelajaran di sekolah sudah dilaksanakan dari pembelajaran tradisional menuju pembelajaran yang modern. Perubahan ini bisa merubah cara pandang terhadap siswa sebagai objek menjadi subjek di dalam proses pembelajaran. Kemampuan pemecahan masalah matematika siswa yang diharapkan meliputi pola kompetensi dan intelegensi, 
pembelajaran bukan hanya menyiapkan masa depan, tetapi juga bagaimana menciptakan masa depan.

Kenyataan yang terjadi hingga saat ini dalam setiap pembelajaran sering ditemukan masalah-masalah yang dialami siswa pada saat pembelajaran sehingga hal ini akan berpengaruh pada kemampuan pemecahan masalah matematika siswa. Pada observasi yang telah dilakukan oleh peneliti saat pembelajaran matematika, guru lebih memilih menggunakan metode ceramah setelah itu siswa diberikan contoh soal-soal yang rutin bahkan latihan soal yang diberikan sama persis dengan contoh soal yang telah dikerjakan oleh guru. Siswa hanya mengikuti saja, tidak ada pertanyaan dari siswa dan latihan soal yang dikerjakan siswa hanya dikumpulkan serta tidak adanya peran aktif siswa dalam proses pembelajaran. Hal ini dapat menyebabkan rendahnya kemampuan pemecahan masalah matematika siswa yang diakibatkan oleh guru yang umumnya terlalu berkonsentrasi pada latihan menyelesaikan soal. Adapun kegiatan pembelajaran guru hanya menjelaskan konsep secara informatif, memberikan contoh soal dan soal-soal latihan. Guru merupakan pusat kegiatan, sedangkan siswa selama kegiatan pembelajaran cendrung pasif. Siswa hanya mendengarkan, mencatat penjelasan dan mengerjakan soal, sehingga pengalaman belajar yang telah dimiliki oleh guru tidak berkembang.

Hal ini harus ada kemampuan pemecahan masalah pada siswa, karena kemampuan ini dapat membantu siswa membuat keputusan yang tepat, cermat, sistematis, logis dan mempertimbangkan berbagai sudut pandang. Selain itu juga harus ada model pembelajaran untuk merubah suasana belajar siswa yang asalnya pasif menjadi aktif, peneliti mengajukan peningkatan kemampuan pemecahan masalah matematika siswa melalui strategi problem based learning. Penelitian yang dilakukan oleh Vebdola, Niniawati, dan Fauziah, (2013: 9) tentang penerapan strategi problem based learning dalam pembelajaran matematika. Hasil penelitiannya adalah pembelajaran problem based learning lebih baik dari hasil belajar matematika siswa yang pembelajarannya menggunakan pembelajaran biasa. Peneliti mengharapkan terdapat peningkatan kemampuan pemecahan masalah matematika siswa melalui strategi problem based learning pada materi bangun ruang sisi datar pokok bahasan prisma dan limas.

Berdasarkan paparan di atas, peneliti merumuskan bagaimanakah upaya meningkatkan kemampuan pemecahan masalah matematika siswa melalui strategi problem based learning pada kelas VIII-C SMP Muhammadiyah 29 Sawangan Depok? Sehingga tujuan penelitian ini untuk mengetahui peningkatan kemampuan pemecahan masalah matematika siswa melalui strategi problem based learning pada kelas VIII-C SMP Muhammadiyah Sawangan Depok. 


\section{KAJIAN PUSTAKA}

Karakteristik matematika adalah sifatnya yang menekankan pada proses deduktif yang memerlukan penalaran logis dan aksiomatik yang diawali dengan proses induktif yang meliputi penyusunan konjektur, model matematika, analogi dan atau generalisasi, melalui pengamatan terhadap sejumlah data. Karakteristik berikutnya, ditinjau dari segi susunan unsur-unsurnya, matematika dikenal pula sebagai ilmu yang terstruktur dan sistematis dalam arti bagian-bagian matematika tersusun secara hierarkis dan terjalin dalam hubungan fungsional yang erat (Sumarmo, 2014: 295).

Pemecahan masalah dipandang sebagai suatu proses untuk menemukan kombinasi dari sejumlah aturan yang dapat diterapkan dalam upaya mengatasi situasi yang baru. Pemecahan masalah tidak sekedar sebagai bentuk kemampuan menerapkan aturan-aturan yang telah dikuasai melalui kegiatan-kegiatan belajar terdahulu, melainkan lebih dari itu, merupakan proses untuk mendapatkan aturan pada tingkat yang lebih tinggi (Hardini dan Puspitasari, 2012: 86-87).

Hal ini sejalan dengan teori Polya bahwa pemecahan masalah membantu siswa dalam membangun kemampuan yang dimilikinya, merangsang untuk menemukan pengetahuan yang baru dan siswa berperan aktif dalam kegiatan pembelajaran. Menurut Polya (1985) dalam Saragih dan Habeahan (2014: 124) pemecahan masalah sebagai suatu kemampuan, dengan indikator yang meliputi kegiatan antara lain sebagai berikut:

1. Memahami masalah;

2. Menyusun rencana penyelesain;

3. Menyelesaikan rencana penyelesaian;

4. Melihat kembali keseluruhan jawaban.

Problem Based Learning (PBL) pertama kali diperkenalkan pada awal tahun 1970-an di Universitas Mc Master Fakultas Kedokteran Kanada, sebagai satu upaya menemukan solusi dalam diagnosis dengan membuat pertanyaan-pertanyaan sesuai dengan situasi yang ada (Rusman, 2012: 242). Menurut Cotton (dalam Tasoglu dan Bakac 2014: 111) problem based learning dapat mendorong siswa untuk berpikir dan memecahkan masalah dalam waktu yang terbatas dan memberikan pengalaman yang dapat mendorong pembelajaran aktif, mendukung dalam mengkonstruksikan pengetahuan, dan secara alami mengintegrasikan pembelajaran yang ada di sekolah dalam kehidupan nyata. Menurut Kyeong (dalam Fatade dkk 2013: 29) problem based learning sebagai model pembelajaran yang unik dan modern dengan pembelajaran yang menginstruksikan pada penyelidikan dan partisipasi siswa. Model problem 
based learning atau disebut juga model pembelajaran berbasis masalah yang membantu siswa dalam memecahkan masalah yang tidak rutin dengan menggunakan keterampilan dan kemampuan siswa.

Menurut Ibrahim dan Nur dalam Rusman (2012: 243) mengemukakan bahwa langkahlangkah pembelajaran berbasis masalah adalah sebagai berikut.

Tabel 1: Langkah-langkah Pembelajaran Berbasis Masalah

\begin{tabular}{|c|l|l|}
\hline Fase & \multicolumn{1}{|c|}{ Indikator } & \multicolumn{1}{|c|}{ Tingkah laku Guru } \\
\hline 1 & $\begin{array}{l}\text { Orientasi siswa } \\
\text { pada masalah }\end{array}$ & $\begin{array}{l}\text { Menjelaskan tujuan pembelajaran, menjelaskan } \\
\text { logistik yang diperlukan, dan memotivasi siswa } \\
\text { terlibat pada aktivitas pemecahan masalah }\end{array}$ \\
\hline 2 & $\begin{array}{l}\text { Mengorganisasi } \\
\text { siswa untuk } \\
\text { belajar }\end{array}$ & $\begin{array}{l}\text { Membantu siswa mendefinisikan dan } \\
\text { mengorganisasikan tugas belajar yang berhubungan } \\
\text { dengan masalah tersebut }\end{array}$ \\
\hline 3 & $\begin{array}{l}\text { Membimbing } \\
\text { pengalaman } \\
\text { individu/kelompok }\end{array}$ & $\begin{array}{l}\text { Mendorong siswa untuk mengumpulkan informasi } \\
\text { yang sesuai, melaksanakan eksperimen untuk } \\
\text { mendapatkan penjelasan untuk menyelesaikan } \\
\text { masalah }\end{array}$ \\
\hline 5 & $\begin{array}{l}\text { Mengembangkan } \\
\text { dan menyajikan } \\
\text { hasil karya }\end{array}$ & $\begin{array}{l}\text { Membantu siswa untuk berbagi tugas dan } \\
\text { merencanakan atau menyiapkan karya yang sesuai } \\
\text { sebagai hasil pemecahan masalah dalam bentuk } \\
\text { laporan, video, atau model. }\end{array}$ \\
\hline 5 & $\begin{array}{l}\text { Menganalisis dan } \\
\text { mengevaluasi } \\
\text { proses pemecahan } \\
\text { masalah }\end{array}$ & $\begin{array}{l}\text { Membantu siswa untuk melakukan refleksi atau } \\
\text { evaluasi terhadap penyelidik terhadap proses } \\
\text { pemecahan masalah yang dilakukan. }\end{array}$ \\
\hline
\end{tabular}

Adapun langkah-langkah strategi problem based learning terhadap konsep bangun ruang sisi datar khususnya pada materi prisma dan limas yang akan dilakukan peneliti di kelas sebagai berikut:

1. Siswa diberikan motivasi dengan menjelaskan tujuan dari materi yang dikaji;

2. Siswa dibuatkan kelompok-kelompok kecil yang terdiri dari 4-5 orang dengan; instruksi dari guru. Kemudian siswa disajikan suatu masalah yang berkaitan dengan materi bangun ruang sisi datar untuk dikaji secara berkelompok;

3. Kelompok diberikan kesempatan untuk mendiskusikan masalah yang diberikan dengan kelompoknya;

4. Setelah masing-masing kelompok menemukan solusinya dengan tepat maka kelompok yang paling cepat itulah kelompok yang mempresentasikan hasilnya;

5. Guru sebagai pendamping untuk membenarkan presentasi yang disampaikan oleh kelompok yang maju; 
6. Guru dan siswa menyimpulkan materi;

7. Selama proses pembelajaran berlangsung guru memberi penilaian terhadap setiap siswa.

Berdasarkan hal tersebut, maka peneliti dapat menyimpulkan bahwa PBL adalah suatu strategi yang memfokuskan pada penyajian masalah untuk diselesaikan oleh siswa dengan tujuan memberikan kesempatan kepada siswa dalam membangun pengetahuannya, kemandirian, berpikir kritis dan berperan aktif dalam proses pembelajarannya. Adapun guru dalam pelaksanaan PBL hanya sebagai fasilitator dan pengontrol dalam pelaksanaan pembelajaran.

Pembelajaran melalui strategi PBL diperlukan langkah-langkah yang khusus yang akan dilalui oleh siswa. Peneliti mengambil langkah-langkah yang dikemukakan oleh Ibrahim dan Nur yang telah dipaparkan di atas, yaitu mengorientasikan siswa pada masalah, mengorganisasikan siswa untuk belajara, membimbing pengalaman individu/kelompok, mengembangkan dan menyajikan hasil karya, dan menganalisis serta mengevaluasi proses pemecahan masalah. Peneliti menerapkan strategi problem based learning di kelas pada materi bangun ruang sisi datar.

\section{METODE PENELITIAN}

Penelitian ini dilaksanaan di SMP Muhammadiyah 29 Sawangan Depok di Jl. Abdul Wahab No. 29 Cinangka Sawangan Depok. Penelitian dilakukakan pada tanggal 02 Mei sampai dengan tanggal 27 Mei 2016.

Subjek pada penelitian adalah siswa kelas VIII-C SMP Muhammadiyah 29 Sawangan Depok dengan jumlah 34 orang terdiri atas 24 orang siswa laki-laki dan 10 orang siswa perempuan.

Jenis penelitian ini adalah Penelitian Tindakan Kelas (PTK) atau Classroom Action Research (CAR). Penelitian ini dilakukan melalui proses kolaborasi antara guru matematika dan peneliti. Ada beberapa ahli yang mengemukakan model penelitian tindakan dengan bagan yang berbeda, namun secara garis besar terdapat empat tahapan yang lazim dilalui, yaitu (Arikunto, 2012: 16):

1. Perencanaan (planning);

2. Pelaksanaan (action);

3. Pengamatan (observing);

4. Refleksi. 
Desain penelitian ini adalah penelitan tindakan kelas dengan alur kegiatan mengikuti desain Model Lewin sebagai berikut (Mulyasa, 2012: 84):

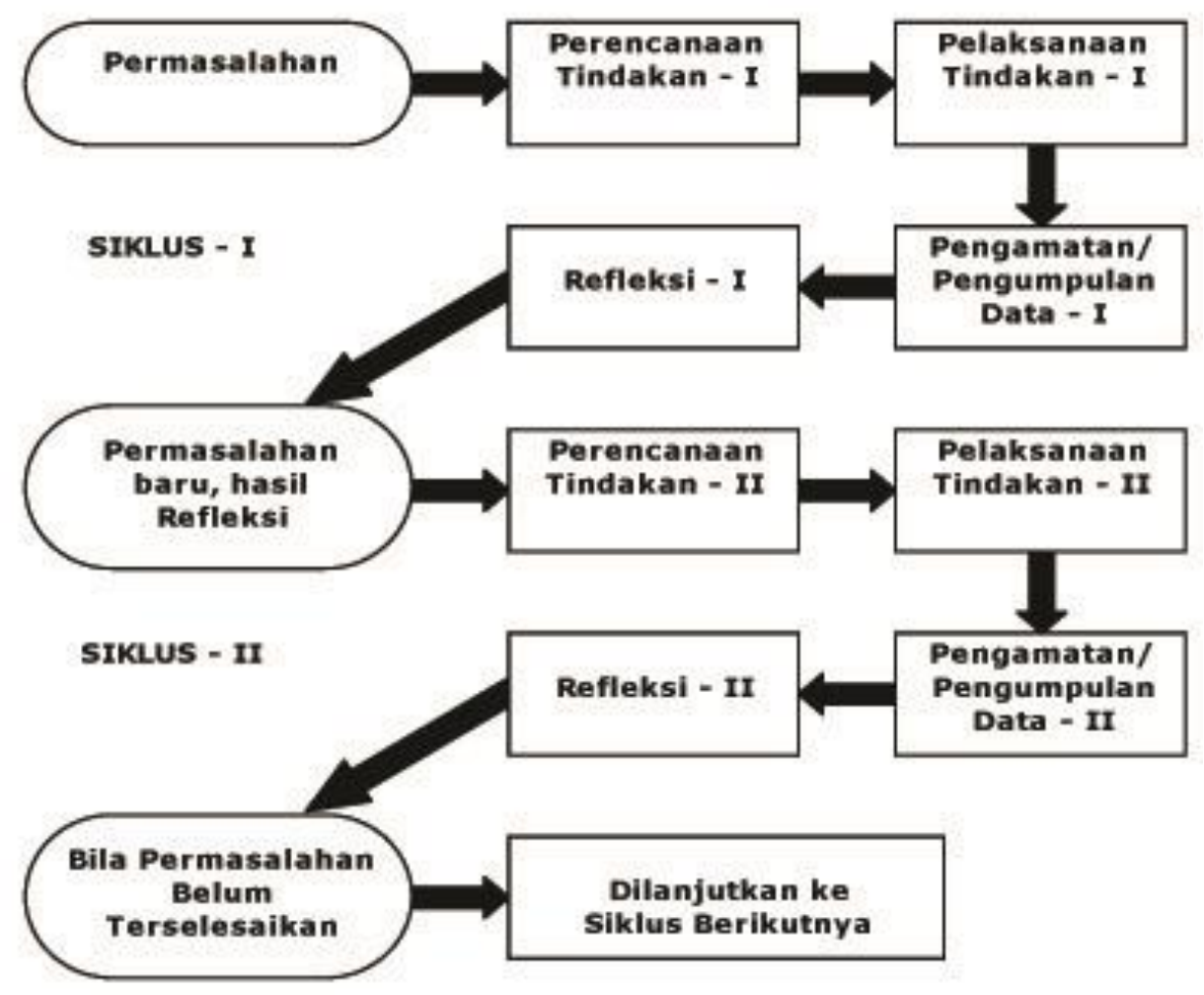

Gambar 1. Desain Model Lewin

Refleksi Awal - Perencanaan Tindakan I - Pelaksanaan Tindakan I - Observasi, Refleksi dan Evaluasi I - Perencanaan Tindakan II - Pelaksanaan Tindakan II - Observasi, refleksi dan Evaluasi II - Perencanaan Tindakan III - Pelaksanaan Tindakan III - Observasi, Refleksi dan Evaluasi III.

Prosedur penelitian biasanya meliputi beberapa siklus, sesuai dengan tingkat permasalahan yang akan dipecahkan dan kondisi yang akan ditingkatkan. Peneliti menggunakan 3 sisklus, yaitu dengan setiap siklusnya terdiri dari; rencana, tindakan, observasi, dan refleksi begitu juga selanjutnya sampai siklus ketiga.

Bersumber pada hasil yang diperoleh dari evaluasi pada setiap pertemuan atau setiap siklus, diharapkan adanya peningkatan kemampuan pemecahan masalah matematika siswa minimal $70 \%$ dari rata-rata pada setiap siklusnya.

Penelitian tindakan kelas yang dilakukan ini bersifat deskriptif kualitatif. Sumber data primer adalah peneliti yang melakukan tindakan dan siswa yang menerima tindakan, sedangkan data skunder yang berupa data dokumentasi. Pengambilan data dapat dilakukan dengan teknik tes uarain, lembar observasi, wawancara, dan dokumentasi. 
Instrumen yang digunakan untuk mengumpulkan data dalam penelitian ini adalah instrumen tes kemampuan pemecahan masalah matematika siswa. Tes kemampuan pemecahan masalah yang digunakan berbentuk uraian yang terdiri dari 4 butir soal yang disesuaikan dengan indikator kemampuan pemecahan masalah teridiri dari; kemampuan memahami masalah, menyusun rencana penyelesaian, menyelesaikan rencana penyelesaian, dan melihat kembali keseluruhan jawaban. Tes tersebut diberikan pada setiap siklus atau setiap pertemuan. Instrumen non tes, yaitu menggunakan lembar observasi yang terdiri dari 23 pernyataan yang diberikan pada setiap siklus atau pertemuan secara langsung diisi oleh guru mata pelajaran matematika sebagai pengontrol. Observasi yang digunakan dalam penelitian ini harus disusun berdasarkan kisi-kisi instrumen pada lembar observasi tersebut. Kisi-kisi non tes bentuk observasi dengan menggunakan indikator strategi problem based learning, hal ini dilakukan untuk melihat kemampuan guru dalam mengelola langkah-langkah model problem based learning yang terdiri dari 5 indikator sebagai berikut:

1. Orientasi siswa pada masalah;

2. Mengorganisasi siswa untuk belajar;

3. Membimbing pengalaman individu/kelompok;

4. Mengembangkan dan menyajikan hasil karya;

5. Menganalisis dan mengevaluasi proses pemecahan masalah.

Teknik analisis data yang digunakan dalam penelitian ini adalah analisis data kualitatif, yang mengikuti konsep yang diberikan Hiles dan Huberman (dalam Arikunto 2011: 37). Aktivitas dalam analisis data yaitu pengumpulan data, reduksi data, penyajian data, penarikan kesimpulan, dan verifikasi. Langkah-langkah analisis data dapat dilihat sebagai berikut. Langkah-langkah analisis data model interaktif pada gambar di atas dapat dijelaskan sebagai berikut:

1. Pengumpulan Data

Data yang diperolah di lapangan dicatat atau direkam dalam bentuk naratif, yaitu uraian data yang diperoleh dari lapangan apa adanya tanpa adanya komentar peneliti yang berbentuk catatan kecil. Berdasarkan catatan deskriptif ini, kemudian dibuat catatan refleksi yaitu catatan yang berisikan komentar, pendapat atau penafsiran peneliti atas fenomena yang ditemukan dilapangan.

2. Reduksi Data

Reduksi data merupakan proses pemilihan, pemusatan perhatian, pada penyederhanaan, pengabstrakan, dan transformasi data kasar yang muncul dari catatan 
lapangan. Reduksi data dilakukan terus menerus selama penelitian dilaksanakan. Reduksi data merupakan wujud analisis yang menajamkan, mengklarifikasikan, mengarahkan, membuang data yang tidak berkaitan dengan pokok persoalan. Tahapan ini disajikan data hasil temuan dilapangan dalam bentuk teks deskriptif naratif.

3. Penarikan Kesimpulan dan Verifikasi

Penarikan kesimpulan dan verifikasi selalu dilakukan peninjauan terhadap penyajian data dan catatan di lapangan melalui diskusi tim peneliti, Miles and Huberman (dalam Sukmadinata 2005: 38).

\section{HASIL DAN PEMBAHASAN}

Berikut disajikan beberapa hasil siklus yang telah dilakukan oleh tim peneliti dalam proses pembelajaran matematika terhadap peningkatan kemampuan pemecahan masalah matematika siswa melalui strategi problem based learning pada kelas VIII-C SMP Muhammadiyah 29 Sawangan Depok, adapun data hasil penelitian siklus I, siklus II dan siklus II dapat dilihat secara rinci sebagai berikut:

\section{Data Siklus I}

Perencanaan; Perencanaan sebelum tindakan dilakukan kegiatan sebagai berikut:

Peneliti bersama teman sejawat (kolabolator) mengadakan diskusi, mempersiapkan instrumen pengamatan, melakukan koordinasi dengan tim pengamat (I dan II) dan penjelasan cara pengisian lembar pengamatan (observasi) beserta tes bentuk uraian.

Pelaksanaan Tindakan; Peneliti melakukan langkah pembelajaran sesuai dengan RPP, Siswa mengikuti kegiatan pembelajaran, Peneliti melakukan pengamatan sesuai dengan instrumen yang telah dibuat.

Observasi; Sasaran observasi penelitian ini adalah proses pembelajaran yang dilakukan peneliti dengan strategi problem based learning terhadap kemampuan pemecahan masalah matematika siswa.

Refleksi; Peneliti dapat mengemukakan penilain yang diperoleh siswa kelas VIIIC dari instrumen tes bentuk urain siklus I terdapat rata-rata 52,5. Adapun siswa yang mendapatkan nilai di atas rata-rata sebanyak 19 siswa dengan persentase sebesar 55,88\% dan 15 siswa dengan nilai di bawah rata-rata dengan persentase sebesar $44,11 \%$. Hal ini berarti tingkat keberhasilan tindakan yang dicapai masih belum memenuhi kriteria keberhasilan tindakan penelitian, hal ini dikarnakan penerapan startegi problem based learning adalah hal yang baru, kurangnya pemahaman siswa dalam mempelajari/menerima yang disampaikan peneliti, kurang sistematis guru dalam 
presentasi dan diskusi kelas, kurangnya motivasi dari guru, kurangnya bimbingan guru dalam diskusi. Oleh karena itu, diperlukan siklus II untuk pembenahan atas kelemahankelemahan tersebut.

\section{Data Siklus II}

Perencanaan; Menetapkan tujuan pembelajaran yang ingin dicapai, mempersiapkan RPP, mempersiapkan instrumen pengamatan yang digunakan untuk siklus II, melakukan koordinasi dengan tim pengamat (I dan II).

Pelaksanaan Tindakan; Peneliti melakukan langkah pembelajaran sesuai dengan RPP dengan berupaya memperbaiki kelemahan-kelemahan pembelajaran yang telah dilakukannya pada siklus I, siswa mengikuti kegatan pembelajaran, peneliti melakukan pengamatan sesuai dengan instrumen yang telah dibuat.

Observasi; Sasaran observasi penelitian ini adalah proses pembelajaran yang dilakukan guru (peneliti) dengan strategi problem based learning terhadap kemampuan pemecahan masalah matematika siswa dengan menggunakan soal bentuk uraian dan penerapan strategi probem based learning dengan menggunakan lembar observasi yang ditinjau langsung oleh guru mata pelajaran yang bersangkutan pada setiap pertemuannya.

Refleksi; Peneliti dapat mengemukakan penilain yang diperoleh siswa kelas VIII-C dari instrumen tes bentuk urain siklus II terdapat rata-rata 58,09. Adapun banyaknya siswa yang mendapatkan nilai di atas rata-rata sebanyak 20 siswa atau secara persentase sebesar 58,82\% dan terdapat 14 siswa dengan nilai dibawah rata-rata dengan persentase sebesar 41,18\%. Hal ini berarti tingkat keberhasilan yang dicapai masih belum memenuhi kriteria keberhasilan penelitian, hal ini dikarnakan penerapan startegi problem based learning masih belum berpengaruh, kurangnya pemahaman siswa dalam mempelajari/menerima yang disampaikan guru (peneliti). Oleh karena itu, diperlukan siklus III untuk pembenahan atas kelemahan-kelemahan tersebut.

\section{Data Siklus III}

Perencanaan; Menetapkan tujuan pembelajaran yang ingin dicapai, mempersiapkan RPP, mempersiapkan instrumen pengamatan yang digunakan untuk siklus III, melakukan koordinasi dengan tim pengamat (I dan II). 
Pelaksanaan Tindakan; Peneliti melakukan langkah pembelajaran sesuai dengan RPP dengan berupaya memperbaiki kelemahan-kelemahan pembelajaran yang telah dilakukannya pada siklus II, siswa mengikuti kegiatan pembelajaran, peneliti melakukan penelitian sesuai dengan instrumen yang telah dibuat,

Observasi; Sasaran observasi penelitian ini adalah proses pembelajaran yang dilakukan guru (peneliti) dengan strategi problem based learning terhadap kemampuan pemecahan masalah matematika siswa dengan menggunakan soal bentuk uraian dan penerapan strategi probem based learning dengan menggunakan lembar observasi yang ditinjau langsung oleh guru mata pelajaran yang bersangkutan pada setiap pertemuannya.

Refleksi; Peneliti dapat mengemukakan penilain yang diperoleh siswa kelas VIII-C dari instrumen tes bentuk urain siklus II terdapat rata-rata 82,94. Adapun banyaknya siswa yang mendapatkan nilai di atas rata-rata sebanyak 24 siswa atau secara persentase sebesar 70,59\% dan terdapat 10 siswa dengan nilai dibawah rata-rata dengan persentase sebesar 29,41\%. Hal ini berarti tingkat keberhasilan tindakan yang dicapai sudah memenuhui kriteria keberhasilan penelitian tindakan. Keberhasilan yang meningkat pada siklus III ini dengan memenuhi kriteria keberhasilan penelitian tindakan artinya peneliti tidak melanjutkan ke siklus sealnjutnya.

\section{Pembahasan Antar Siklus}

Berdasarkan uraian tiap-tiap siklus dapat peneliti simpulkan bahwa dalam setiap siklus terlihat ada peningkatan, strategi problem based learning terhadap kemampuan pemecahan masalah matematika siswa melalui pengukuran instrumen tes bentuk uraian dan instrumen non tes dengan lembar observasi, wawancara dan catatan lapangan. Pembahasan antar siklus ini dapat dilihat secara rinci pada tabel 2 dan gambar 2. grafik sebagai berikut:

Tabel 2: Rekapitulasi Hasil Evaluasi Siklus

\begin{tabular}{|c|c|c|c|}
\hline Siklus & Rata-rata & Ketuntasan & Penerapan PBL \\
\hline Pra Siklus & 50.58 & $49.41 \%$ & $0 \%$ \\
\hline Siklus I & 52.5 & $55.88 \%$ & $69.57 \%$ \\
\hline Siklus II & 58.09 & $58.88 \%$ & $78.26 \%$ \\
\hline Siklus II & 82.9 & $82.90 \%$ & $82.61 \%$ \\
\hline
\end{tabular}




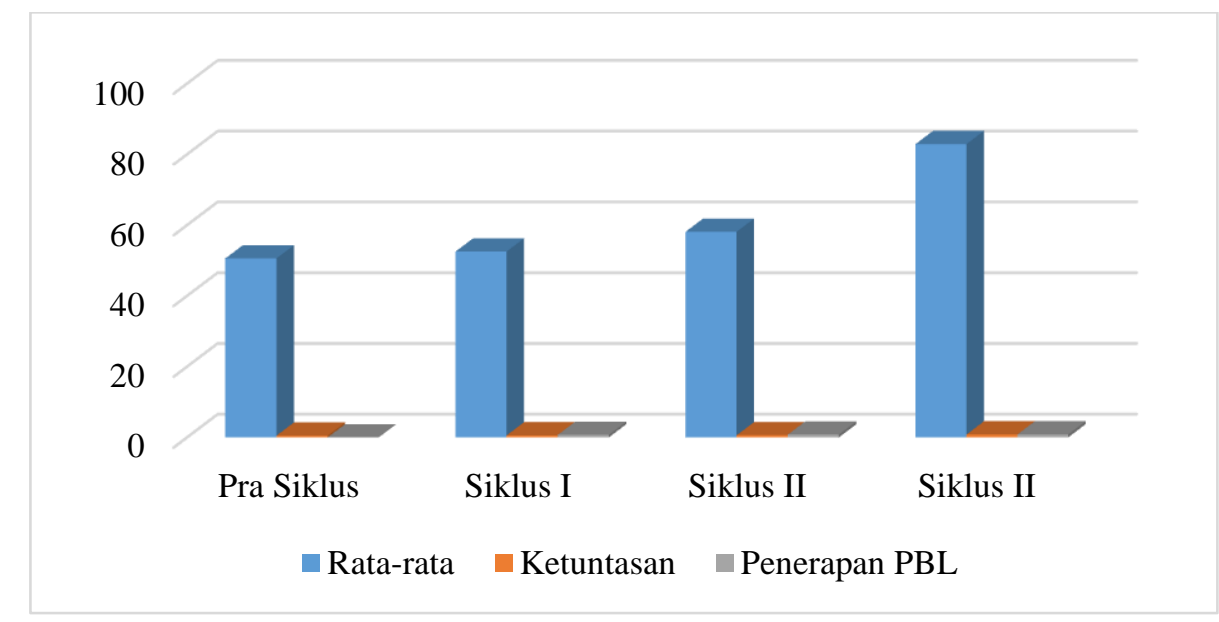

\section{Gambar 2. Grafik histrogram nilai evaluasi siklus dan penerapan PBL}

Peningkatan antara kondisi awal dengan siklus I khususnya pada rata-rata kemampuan pemecahan masalah matematika siswa dari 50,58 menjadi 52,5, jadi masih jauh dari kriteria keberhasilan penelitian tindakan hal ini disebabkan antara lain: bagi siswa strategi problem based learning adalah hal baru, siswa belum terbiasa belajar dengan menggunakan strategi problem based learning sebab selama ini pembelajaran berlangsung secara tradisional sehingga keberanian siswa untuk menjawab atau mengeluarkan pendapat tidak ada, peneliti pada siklus ini belum begitu dapat mengusai skenario pembelajaran, bagian mana yang harus diberi penguatan-penguatan dan masih banyak kelemahan atau kekurangan pada siklus ini.

Antara siklus I, II dan III terdapat perkembangan dan peningkatan pada setiap siklusnya begitu menggembirakan baik bagi peneliti dalam setiap evaluasi dari hasil pengamatan terbukti untuk rata-rata kemampuan pemecahan masalah matematika kelas VIII-C hasil evaluasi dari siklus I sebesar 52,5 dengan persentase siswa di atas nilai rata-rata sebesar $55,88 \%$, adapun hasil lembar observasi pada penerapan PBL menunjukkan persentase sebesar 69,75\% pada siklus I. Kemudian meningkat lagi pada siklus II sebesar 58,09 dengan persentase siswa di atas nilai rata-rata sebesar 58,82\%, adapun hasil lembar observasi pada penerapan PBL menunjukkan persentase sebesar 78,26\% pada siklus II. dan pada siklus III meningkat baik sebesar 82,94 dengan peresentase siswa di atas nilai rata-rata sebesar 70,59\%, adapun hasil lembar observasi pada penerapan PBL menunjukkan persentase sebesar 82,61\% pada siklus III. Hal ini disebabkan siswa sudah semakin akrab dengan strategi problem based learning, kerja kelompok atau diskusi kelompok pun sudah terlihat kekompakannya, keberanian siswa untuk mengeluarkan pendapat sudah mulai baik, penelitipun dalam menguasai keadaan atau situasi kelas sudah mulai baik. Penelitipun menganalisis hasil terhadap indikator pemecahan masalah yang disajikan sebagai berikut ini. 
Tabel 3: Rekapitulasi Hasil Evaluasi Siklus dengan Melihat Presentase (\%) Indikator Kemampuan Pemecahan Masalah

\begin{tabular}{|c|c|c|c|c|c|}
\hline \multirow{3}{*}{ Siklus } & \multirow{2}{*}{$\begin{array}{c}\text { Rata- } \\
\text { Rata }\end{array}$} & \multicolumn{4}{|c|}{ Presentase (\%) Indikator Pemecahan Masalah } \\
\cline { 3 - 6 } & & Memahami & Melaksanakan & Melaksankan & Interpretasi \\
\cline { 3 - 6 } & 63.9 & 84.73 & Strategi & Perhitungan & Solusi \\
\hline Siklus III & 62.04 & 70.97 & 27.53 \\
\hline
\end{tabular}

Siklus III

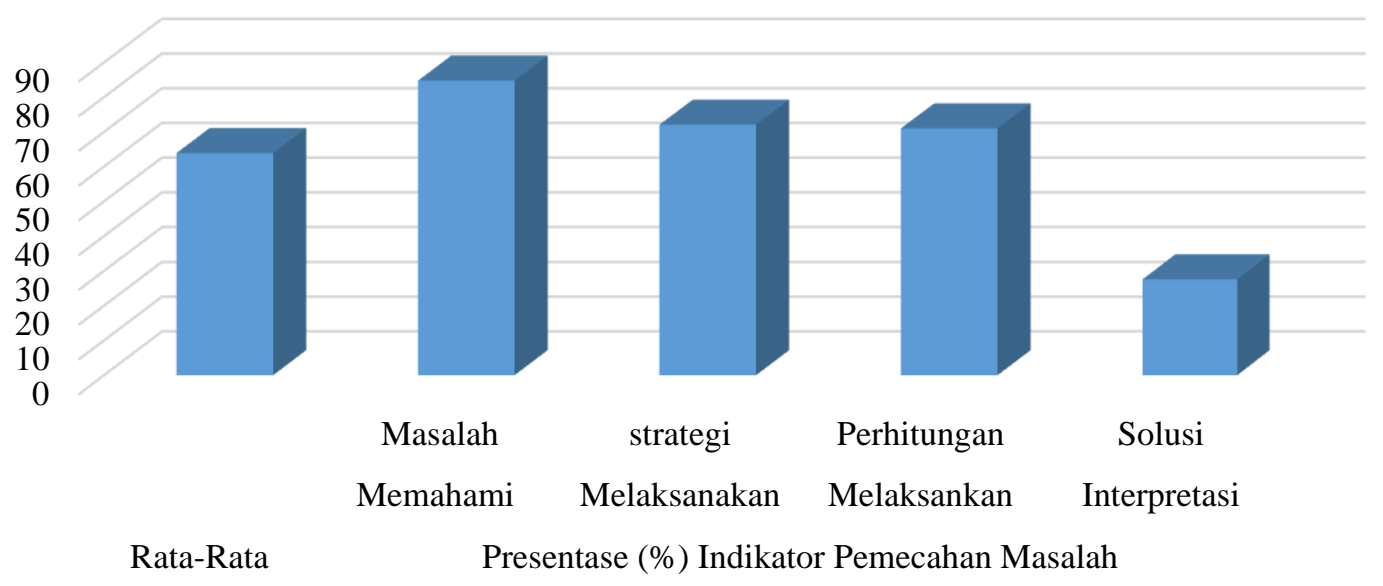

Gambar 3. Grafik Histrogram Peresentase (\%) Indikator Kemampuan Pemecahan Masalah

Berdasarkan tabel 2 tersebut menunjukkan dengan jelas bahwa setiap siklus terdapat peningkatan yang signifikan terhadap kemampuan pemecahan masalah matematika siswa kelas VIII-C melalui strategi problem based learning, adapun berdasarkan tabel 3 dan gambar 3, grafik kemampuan pemecahan masalah yang terdiri dari 4 indikator pemecahan masalah matematika, yaitu memahami masalah dengan persentase yang ditunjukkan sebesar 84,73\%, menyusun rencana dengan persentase sebesar $72,04 \%$, menyelesaikan rencana penyelesaian dengan persentase sebesar 70,97\% dan memeriksa kembali keseluruhan jawaban dengan persentase sebesar 27,53\%. Hal ini berarti dikatakan bahwa indikator pemecahan masalah matematika dan penerapan strategi problem based learning terhadap kemampuan pemecahan masalah matematika siswa pada materi bangun ruang sisi datar pokok bahasan prisma dan limas kelas VIIIC di SMP Muhammadiyah 29 Sawangan-Depok Tahun Pelajaran 2015/2016 dapat tercapai.

\section{SIMPULAN}

1. Kemampuan pemecahan masalah matematika pada materi bangun ruang sisi datar pada pokok bahasan prisma dan limas dengan menggunakan strategi problem based learning 
meningkat pada setiap siklus yang diamati. Ini terlihat pada nilai rata-rata yang diperoleh pada setiap siklusnya ada peningkatan, yaitu pada siklus 1 sebesar 52,5 dengan tingkat persentase sebesar 52,88\% meningkat pada siklus II sebesar 58,09 dengan tingkat persentase sebesar 58,82\% dan meningkat lagi pada siklus III sebesar 82,9 dengan persentase $82,90 \%$.

2. Penerapan strategi problem based learning terhadap kemampuan pemecahan masalah matematika siswa menunjukkan peningkatan pada setiap siklusnya. Hal ini terlihat dari hasil perhitungan lembar observasi berdasarkan 5 indikator, yaitu pada siklus I sebesar 69,75\% meningkat pada siklus II sebesar 78,26\% dan pada siklus III meningkat sebesar $82,61 \%$. Pembelajaran melalui strategi problem based learning memberikan suasana belajar yang baru. Siswa yang lebih aktif membangun sendiri pengetahuan di dalam benaknya melalui soal yang diberikan dengan memuat konsep bangun ruang sisi datar pokok bahasan prisma dan limas.

\section{DAFTAR PUSTAKA}

Arikunto, Suharsimi. (2011). Penelitian Tindakan Kelas. Jakarta: PT Bumi Aksara.

Fatade Olufemi, Alfred, dkk. (2013). "Effect of Problem-Based Learning On Senior Secondary School Students' Achievements in Further Mathematics". Acta Didactica Napocensia. Vol 6(3). 01-44.

Rusman. (2012). Seri Manajemen Sekolah Bermutu Model-Model Pembelajaran Mengembangkan Profesionalisme Guru. Jakarta: PT RajaGrapindo Persada

Sugiyono. (2013). Metode Penelitian Kuantitatif, Kualitatif, dan $R \&$ D. Bandung: Alfabeta.

Tasoglu, Kartal Aslihan dan Bakac, Mustafa. (2014). "The Effect of Problem Based Learnin Approach on Conceptual Understanding in Teaching of Magnetism Topics". Eurasian Journal of Physics and Chemistry Education. Vol 6(2), 110-122.

Vebdola, Niniawati dan Fauziah. (2013). "Peningkatan Aktivitas Dan Hasil Belajar Melalui Strategi Problem Based Learning Pada Kelas X SMA”. Vol 42(2). 25-65.

\section{UCAPAN TERIMAKASIH}

Ucapan terima kasih kami sampaikan kepada Direktorat Jenderal Pendidikan Tinggi (Dirjen DIKTI) yang telah membiayai sepenuhnya penelitian ini dalam Program Kreatifitas Mahasiswa (PKM) dalam Skema Penelitian tahun 2015. 